\title{
Z KRĘGU WYOBRAŻEŃ MOTYWU WSTYDU W SZTUCE. WYBRANE ZAGADNIENIA W SZTUCE ŚREDNIOWIECZNEJ EUROPEJSKIEJ I POLSKIEJ
}

\section{WPROWADZENIE}

Wstyd jako przykre, upokarzające uczucie, spowodowane świadomością niewłaściwego postępowania własnego lub cudzego, połączony jest z lękiem przed opinią rozpoznającego owo złe postępowanie. Wstyd jest doświadczeniem wewnętrznym człowieka, należącym do sfery uczuć. Może być uzewnętrzniony w zachowaniu człowieka, jego specyficznym ruchu, np. pochyleniu ciała, ukryciu twarzy, odwróceniu wzroku. W literackich tropach wstyd 'okrywa' twarz, 'można najeść się wstydu' za własne lub czyjeś postępowanie. Wstyd może być rozumiany w jedności z niewinnością, pięknem, honorem, ,nawet uroda we wstydzie chowana jest jako cnota"1. Wstydliwość rozumiana zamiennie ze wstydem w historycznej obyczajowości przynależała do uczuć przypisanych kobietom, pannom, natomiast honor odnoszono do mężczyzn. Wstyd może dotyczyć uczuć rodziny, rodu, miasta, narodu, grupy społecznej. Uczucie wstydu w rozumieniu obyczajowości, w tym także w przeżyciach i w zachowaniu norm religijnych, wprowadza do bardzo zróżnicowanych ocen i podstaw

W. D o r o s z e w s k i (red.), Stownik języka polskiego, t. IX, Warszawa 1967, s. 1351. 
jego odczuwania bądź braku odczuwania. Jednocześnie nieodczuwanie wstydu nie jest jednoznaczne z bezwstydem.

Obrazowanie w sztuce szeroko rozumianego wstydu w różnych scenach lub pojedynczych postaciach wyprowadza się z badanych tekstów religijnych, a także z obszaru psychologii, obyczajowości, moralności i etyki, i powinno być ostatecznie skorygowane $\mathrm{z}$ wiedzą o wychowaniu i edukacji młodzieży, a w szerszym znaczeniu społecznej paidei. Analiza wstydu w sztuce, podobnie jak innej skali uczuć i emocji, wymaga dotarcia do adekwatnych źródeł, głównie Biblii, ale również i komentarzy biblijnych, podręczników katechetycznych, komentarzy etycznych oraz moralnych i analiz różnych zjawisk obyczajowości, które przenikały do sztuk wizualnych i poprzez nie utrwalały swoje zrazu znikomo zarysowane, a następnie rozpowszechniane wzorce realnych zachowań. Istotna jest kwestia przedmiotu wstydu i stopnia świadomej reakcji nań podmiotu refleksyjnego. Tego, co było powodem wstydu w historycznej pespektywie zachowanych motywów w sztuce europejskiej, nie możemy ukazać w krótkiej analizie zjawiska w stopniu zadowalającym. Chcemy wskazać jedynie rangę problemu, nie mającego zresztą w sztuce odrębnych badań. Zatem unaoczniona w sztuce postać lub sposób wykreowanego zdarzenia, wprowadzający do refleksji o uczuciach wstydu, wymaga uważnej refleksji, musi być analizowany na podstawie konkretnych wyobrażeń, bowiem zaskakujące są różnice w rozumieniu i odczuwaniu wstydu nawet $\mathrm{w}$ tradycyjnie pojętych kategoriach chrześcijańskiej kultury europejskiej. W znacznym stopniu potwierdzają to liczne studia z zakresu historii kultury duchowej i materialnej, np. mody w ubiorach kobiecych i męskich, obrzędowości. Tym bardziej wrażliwa na poczucie wstydu jest wizualizacja moralna czynów, zdarzeń, postaci. Dzięki wysubtelnionym, sugestywnie przekazywanym środkom artystycznym (np. odlewy z brązu, marmury, polichromowana snycerka czy malarstwo zwłaszcza monumentalne) problem unaoczniania wstydu lub wstydliwości zyskiwał bogatą skalę zmysłowego wyrazu. Zwykło się odnosić nagość człowieka do pojęcia, tudzież wizualizacji jako pierwszego i najbardziej wrażliwego przedmiotu wstydu, przynajmniej w europejskiej kulturze chrześcijańskiej. Jeżeli 
jednak bliżej przypatrzymy się temu zagadnieniu i odniesiemy sposób ukazywania nagości do źródeł sztuki europejskiej - wizualizacji antycznej grecko-rzymskiej, a szczególnie wschodniej, dostrzeżemy poważne trudności w jednoznacznej ocenie. Nagość w rozumieniu historycznym, zwłaszcza na podłożu biblijnym, nie była jednoznacznym odniesieniem do wstydu lub jego braku.

W niniejszym rozważaniu chcemy ten bardzo szeroki problem zawęzić do wybranych zagadnień w sztuce średniowiecznej, ale de facto mógłby być on rozpatrywany również w badaniach nad sztuką nowożytną i współczesną. Podejmujemy zagadnienie wstydu jako podstawowej kondycji duchowej, stanowiącej o człowieczeństwie, ponad akcydentalnie rozumianymi obyczajami, zmiennymi w historycznej przeszłości, regulowanymi zasadami obowiązującymi w określonych grupach społecznych, etnicznych czy religijnych. Wstyd pojmujemy jako istotę nierozdzielnego zbioru, który stanowi o cnocie razem z duszą, wolą i rozumem. Problem podejmowany w historii religii i filozofii, przeniesiony do historii sztuki, wymaga podjęcia określonej niesprzecznej tkanki literackiej, którą jest dla nas Biblia oraz wybrane teksty autorytetów teologicznych, mających swoje potwierdzenie w istniejących badaniach krytycznych. Przyjmujemy w naszej analizie historii sztuki metodę ikonologiczną, wspieraną metodą lingwistyczną.

W naszych rozważaniach proponujemy przyjąć dla analiz odrębnie pojęcie i wizualizację wstydu oraz pojęcie i wizualizację wstydliwości. W istocie ludzkie uczucia są nierozłączne, trudno byłoby wykluczyć jedno z nich, jednak w zamyśle naszego rozważania klarowne będzie ich rozdzielenie. Wstydliwość jako zdolność odczuwania wstydu, tym samym uzdatnienie emocji do unikania bezwstydu, utożsamiana była z pokorą, nieśmiałością, skromnością czystością. Jest stałym komponentem cnotliwości i kondycji moralnej człowieka. Wstyd jest reakcją na konkretny czyn, określa jakość uczucia i emocji, które może rozbudzić ktoś, napominając do zawstydzenia za popełniony czyn lub ostrzegając przed popełnieniem czynu zła. 


\section{WSTYD W ŚWIETLE BIBLII}

Biblia określa podstawę uczucia wstydu jako rezultat przekroczenia prawa Bożego, popełnienia grzechu wobec Boga i bliźniego rozumianego osobowo lub w kategoriach nacji. Według proroka Zachariasza wrogowie Izraela okryci byli hańbą (Za 10,5). Znamienne jest $\mathrm{w}$ tekstach biblijnych częste odniesienie do twarzy, która jest lustrem wstydu. Twarz wolna od występku promienieje radością i jasnością oblicza (Ps 34, 6), zaś wstyd okrywa twarz (Ps 44, 16; 86, 17; 119, 31). Jest jednak nadzieja, bowiem pokuta i wstyd (odbite na twarzy) są nadzieją na powrót do Boga (Ez 7, 18; Ps 119, 6; 119, 31); wstyd jest także podstawą przebaczenia w modlitwie Daniela (Dn 9, 7-8). Gwarantem człowieka, aby nie doznać wstydu, jest Bóg. Tylko On może chronić przed wstydem, stąd doznawanie wstydu jest łaską Boga (Ps 25, 2; 31,18; 86, 17; 119, 31; Iz 45, 24; Jr 51, 51). Prorok Joel naucza, że gdzie jest Jahwe, tam człowiek nie zazna wstydu (Jo 2, 27). Wstyd w tekstach biblijnych wskazuje na grzechy niewierności wobec Boga. Bóg okrywa wstydem ciemiężyciela, a ochrania uciemiężonego (Mi 7, 10; 10, 5; Jr 51, 51; Ps 44, 8) przed tymi, którzy nienawidzą, aby ujrzeli ze wstydem opiekę Boga (Ps 86, 17).

Wstydem w tekstach biblijnych powinno być bałwochwalstwo. Człowiek powinien się wstydzić z powodu oddawania czci bożkom, drzewom - terebintom (Iz 1, 29), a nawet z powodu wykonywania bożków przez złotników (Iz 44, 11; Jr 10, 14). Biblijny autor ostrzega mędrców, że będą zawstydzeni za „kłamliwe pióro pisarzy” (Jr 8, 9). Wstyd okrywa twarz, co potwierdza również starotestamentalne odbicie wstydu deformującego oblicze. Gorszy jednak, w szerszym kontekście, od wstydu jest jego brak - bezwstyd, który niszczy twarz; nie jest już ona obliczem. Ten aspekt można w sztuce wykazać nazbyt obficie, zarówno w malarstwie i w plastyce. Bezwstyd deformuje całą cielesność człowieka, co ukazuje sztuka średniowieczna. Nawet bardzo syntetyczna analiza wstydu w Biblii wskazuje, że ciało i nagość nie mają ani jedynego, ani zasadniczego podłoża uczucia wstydu, acz jest on opisany w odniesieniu do niewiasty cudzołożnej (Jr 3, 3; Prz 6, 33); grzech popełniony w raju przez pierwszych Rodziców 
opisany jest jako zaznanie wstydu własnym ciałem, nagością, choć jest to rezultat grzechu, a nie jego przyczyna, którą jest złamanie zakazu Bożego.

\section{OJCOWIE KOŚCIOLA O WSTYDZIE}

W kręgach Ojców Kościoła wskazuje się jako cnotę podstawową pokorę, z niej wynikają i zarazem łączą się w zachowaniu i w czynach człowieka: skromność, uniżoność, posłuszeństwo. Cnota uniżoności jest najmilsza Bogu. W hymnie Magnificat Maryi zawarte zostało biblijne ostrzeżenie dla memento pysznych, których Bóg poniża, rozprasza, strąca z tronów, a wywyższa pokornych ${ }^{2}$. Św. Augustyn wskazuje na istotę grzechu jako na pyszną zuchwałość. W obrębie stoickiego rozumienia człowieka cnotliwego, czyli pielęgnującego wszystkie cnoty, upatruje się również cnotę wstydu za winy. Wstyd nie był jednak w starożytności uczuciem winy za czyn zły i niegodziwy. Arystoteles w Etyce Nikomachejskiej wyjaśnia sens wstydu wynikającego z doświadczania pozycji wyróżnionej lub wyższej w statusie społecznym, co jest niemal identycznie rozumiane z pokorą: „człowiek słusznie dumny (...) do niewielu tylko rzeczy przywiązuje wagę; stawia natomiast czoło niebezpieczeństwom, kiedy idzie o rzeczy ważne (...). I skłonny jest do świadczenia dobrodziejstw, lecz kiedy ich doznaje, wstydzi się․

Sumaryczne rozumienie cnót jako pełni wszystkich uwarunkowań w kondycji duchowej człowieka dobrze ilustrują personifikacje z czasów antycznych, zwłaszcza rzymskich. Wyobrażano je jako jedną postać, w której uosabiano wszystkie cnoty stanowiące habitus człowieka. Relief z okresu Nerona ukazuje personifikację Virtus - młoda kobieta z obnażonym torsem, w hełmie na głowie, unosi miecz i lancę.

2 M. S z r a m, Cnota pokory w nauczaniu greckich Ojców Kościoła IV wieku, Lublin 2014, s. 31. Dziękuję Księdzu Profesorowi za cenne uwagi naukowe, które były mi pomocne w podjęciu tego tematu.

3 A r y s t o te le s, Etica nicomachea IV,7,1124a-8,1125; za: M. S z r a m, dz. cyt., s. 21. 
Celowe jest tutaj obrazowanie wątłości młodego ciała kobiecego jako materii, ma być bowiem przeciwstawieniem walki sile ducha jako sumy cnót. Virtus winien człowiek zdobywać w walce, ponieważ nie jest ona dana $z$ urodzenia ani z silnego ciała fizycznego ${ }^{4}$.

Uczucie wstydu dla niektórych pisarzy chrześcijańskich było wynikiem braku łaski i grzechu. Św. Jan Damasceński, rozróżniając sześć gatunków grzechu, wprowadził wstyd do wspólnej grupy z gnuśnością, hańbą, osłupieniem, niepokojem. Tę interpretację krytykuje św. Tomasz z Akwinu jako niewłaściwe wyjaśnienie wstydu, gdyż, jak wskazuje, przedmiotem bojaźni jest zło zasmucające. Bojaźń dotyczy zła, które przekracza nasze władze, także gnuśności, wstydu, hańby, tym samym, jak tłumaczy Akwinata - dotyczy naszych czynności, podczas gdy wstyd jest uczuciem ${ }^{5}$. Jak bardzo jest to złożony problem, świadczy fakt umieszczenia wstydu w innym jeszcze miejscu Sumy Teologicznej. Autor określa wstyd jako rodzaj czynności dokonanych, za które można bać się. Są one hańbą albo utratą czci, czyli wstydem. Tomasz z Akwinu wyjaśnił wstydliwość jako pudicita - ukrywanie tego, co winno być ukryte, a szczególnie nagości tych części ciała, które stanowią o płciowej odrębności ${ }^{6}$. Akwinata wprowadził uczucie wstydliwości do szerszego zakresu wszelkiego odsłonięcia tego, co ktoś pragnie, by pozostawało ukryte, nie tylko w odniesieniu do zła, ale i w stosunku do dobra. Wstydzimy się, gdy chwalą nas za dobre uczynki, gdyż wówczas samo uzewnętrznienie dobra odczuwa się jako coś złego. Do uczucia wstydu zbliżone jest uczucie zawstydzenia, którego doznajemy, gdy odsłonięte zostaje to, co wolelibyśmy, aby pozostało w ukryciu?

Zarysowane powyżej najważniejsze aspekty związane z rozumieniem wstydu i wstydliwości odnieść chcemy do kontekstu wyobrażeń

4 Rzym, Museo Nazionale Romano - za: Enciclopedia dell'Arte Antica Classica e Orientale, t. VIII, Roma 1966, s. 1185.

5 Św. To mas z z A k w i nu, Suma teologiczna, t. X: Uczucia (I-II, q. 22 48), (tłum. J. Bardan), London 1965, s. 260.

6 Tamże, s. 338.

7 Tamże, s. 339. 
w sztuce, świadomi niezwykłej złożoności problemu. Zagadnienie to nie doczekało się jeszcze pełnych badań ani z zakresu ikonografii, ani personifikacji, ani też cech postaci ukazanych w określonych zdarzeniach. Odrębne zagadnienie wstydu złączone jest z unaocznianiem w sztuce tematów płci oraz seksualności w odniesieniu do zachowań społecznych, podjętych w monografiach dotyczących obyczajowości, życia codziennego, które nie podejmują analizy pod kątem cnót ${ }^{8}$.

\section{WIZUALIZACJE WSTYDU}

W niniejszych rozważaniach chcemy jedynie przedstawić niektóre wizualizacje uczucia wstydu na przykładach wybranych personifikacji, niektórych zdarzeń biblijnych, które w swojej istocie wywołują uczucie wstydu - różnie akcentowanego w sztukach plastycznych. Dla nas najistotniejsze będzie wskazanie na dwa sceniczne wyobrażenia ilustrujące wstyd pierwszych Rodziców w scenach po dokonaniu grzechu pierworodnego oraz dostrzeżenie wstydliwości, która widoczna jest w postaci Maryi w scenie Zwiastowania. Wstyd rozumiany jako doznanie w wyniku przekroczenia prawa, wstydliwość jako cecha idealnej kondycji duchowej człowieka, która należy do sumy cnót kształtujących jego świętość lub drogę do świętości.

Personifikacje jako odmiany metafory w sztukach wizualnych służyły unaocznieniu zjawisk abstrakcyjnych, w tym natury, kosmosu, także uczuć i stanów duchowych człowieka, do których należą cnoty i wady. W ikonografii chrześcijańskiej, skierowanej głównie do środowisk klerykalnych i zakonnych, rychło stały się również obrazowym katechizmem aktualnym dla wszystkich wiernych. Interesujący nas motyw wstydu w sztuce zestawiany był najczęściej w przeciwstawieniach wstydu i bezwstydu, skromności i nieskromności,

8 A. Corbi n, J. Vi g a re 11 o (red.), Histoire du corps, t. I-III, Paris 2005 (tłum polskie T. Stażyński, Historia ciała, t. I-III, Gdańsk 2011); P. V e y n e (red.), Historia życia prywatnego, t. I-II, (tłum. W. Gilewski, K. Skawin), Wrocław 1998; J. Le G of f, N. Tr o u n g, Historia ciała w średniowieczu, (tłum. I. Kania), Warszawa 2006. 
wyuzdania, czystości i nieczystości. W katalogu cnót i wad Virtus i Vices personifikacja Castitas, już od tradycji antycznej rozumiana jako nienaganne życie, wprowadzona jako nadrzędna do katalogu cnót - Virtus kobiecych, łączyła w swoim rozumieniu czystość, wstydliwość i skromność. Personifikację cnoty czystości ukazywano w sztuce średniowiecznej i nowożytnej w akcie kobiecym, oznaczającym miłość małżeńską, macierzyńską i płodność, którą uosabiała bogini płodności Wenus, dla której pierwowzorem była Afrodyta z Knidos Praksytelesa, kopiowana także w Rzymie cesarskim jako Wenus Pudica. W uproszczeniach i stylizacjach naśladowano tę postać w średniowieczu. Dzieje Afrodyty - rzymskiej Wenus są znacznie bogatsze aniżeli to, co możemy w tym miejscu wskazać. Faktem jest, że dla średniowiecznej i nowożytnej sztuki jest ona modelem wizualizacji ideału cielesności kobiecej oraz cnót duchowych. Naga postać bogini nie jest ukazana w triumfującym, reprezentacyjno-frontalnym modelu figuratywnym, ale jej gesty, ruch oddają sugestywnie treść dotyczącą „ochrony” swojego nagiego ciała, niejako „odziania” go cnotą wstydliwości, zawartą w pojęciu ogólnym Arete. Jej przeciwieństwem były pożądliwość, wyuzdanie, a więc negatywne cechy, których pozbawiona była boska Afrodyta - rzymska Wenus. Bezwstyd ukazywano w postaciach frontalnie skierowanych, bez gestów przysłaniających ciało.

Podróżnik angielski, znany w literaturze jako Mistrz Gregorius, w swoim dziele z przełomu XIII i XIV wieku pt. Narratio de Mirabilius Urbis Romae przekazał, że widział serię statui z brązu i marmuru przedstawiających nagą boginię Wenus, które stały wokół Lateranu, na placach i wokół świątyń pogańskich i chrześcijańskich. Badacze kodeksu wskazują, że podróżnik ten mógł widzieć rzeźbę z marmuru, którą dzisiaj znamy jako Venus Kapitolińską z III wieku po Chrystusie (obecnie Neapol, Museo Archeologico Nazionale) ${ }^{9}$. Nagi akt młodej bogini ujęty został przez Praksytelesa w kontrapoście,

9 J. C. L o n g, The Survival and Reception of the Classical Nude: Venus in the Middle Ages, w: The Meaning of Nudity in Medieval Art, ed. S.C.M. Lindquist, Burlington (USA) 2012, s. $47 \mathrm{nn}$. 
w delikatnym pochyleniu głowy oraz nieznacznym ruchu prawej dłoni i uniesionej lewej do poziomu bioder. Artysta utrwalił dla sztuki na długie wieki sposób wizualizacji wstydliwości kobiecej, mimo że nagość bogini nie była synonimem rozwiązłości, bowiem była rozumiana jako wzór cnót: miłości, płodności i czystości małżeńskiej.

Sztuka chrześcijańska w okresie wczesnego średniowiecza z dystansem jednak podejmowała problem unaoczniania nagości kobiecej, akceptowanej jedynie w koniecznych sytuacjach: pierwszych Rodziców w raju lub męczeństwa świętych. Antyczny pierwowzór znany z zachowanych monumentów, jak zapewnił Mistrz Gregorius, musiał poczekać na właściwe rozumienie funkcji sztuki i wizualizacji nagości cielesnej. Afrodyta-Wenus była niewątpliwie najstarszym uosobieniem stanu wstydliwości i czystości. Dopóki nie powróciły w sztuce ponownie unaoczniane zdarzenia mitologicznej narracji, Wenus w renesansie była figurą jednoczącą w swojej formie ideały duchowe, których nie odnoszono wyłącznie do sfery płci i seksualności.

W dojrzałym średniowieczu, w XII wieku znanym jako renesans średniowieczny, nagą boginię Wenus raz utożsamiano z wszelkimi demonicznymi odczuciami, w tym z bezwstydem, co było rezultatem jej nagiego ciała, innym razem odwoływano się do sensu jej boskości, czyli ideału cnót, zwłaszcza cnoty Castitas. Gesty, kontrapost oraz specyficzne pochylenie głowy, stawały się wizualnym językiem komunikacji przekazującej w formie plastycznej ideały czystości, obyczaju i nienagannego życia, które rozumiano zarówno w odniesieniu do ciała, jak i ducha, wszelkiej obyczajności, postępowania, w tym cnoty Prawdy. Zatem wstyd nie dotyczył tylko nagości jako nieobyczajności. Castitas ukazywano jako piękną personifikację młodej kobiety o nienagannej figurze, ukształtowanym harmonijnie ciele, które obrazować miało harmonię duchową. Piękny kształt ciała oddawał idealne piękno wewnętrzne, pełne cnót adekwatnych dla mężczyzny i dla kobiety. W odniesieniu do kobiet Castitas oznaczała także miłość i czystość małżeńską. W greckim systemie wizualizacji cnót, zwłaszcza w postaciach bogiń, ukształtowane zostały pierwowzory formalne, kopiowane także w sztuce rzymskiej i adaptowane w odpowiedniej modyfikacji w ikonografii chrześcijańskiej. Dlatego 
w niej należałoby upatrywać początku charakterystycznego modelu wizualizacji dla wszystkich późniejszych -średniowiecznych i nowożytnych - wyobrażeń wstydliwości kobiecej, mimo że często w piśmiennictwie chrześcijańskim nie zawsze odczytywano jej pierwotny sens.

Nagość, zwłaszcza kobieca, w swoim tylko ziemskim rozumieniu była potępiana. Poddana grzechowi rozpusty i pożądliwości ciała, personifikowana była przez rozwiązłość i bezwstyd - Luxuria unaoczniana w rzeźbach romańskich katedr, np. w fasadzie katedry św. Piotra w Moissac, datowanej na rok 1120 (Langwedocja) albo na kapitelu w kościele św. Łazarza w Autun (Burgundia) z roku 1140. Cielesność personifikacji Luxurii była jednak ukazywana w znacznej deformacji, brzydocie, co wyraźnie przeczyło słowom „na obraz i podobieństwo", a stojący obok personifikacji demon podkreślał jej demoniczne działanie.

Błędem byłoby przyjmować nagość, szczególnie kobiecą, jako jedyne kryterium cnót, zwłaszcza w celu wyjaśnienia sensu cnoty Wstydliwości. Nagość nie była w sztuce średniowiecznej jednoznacznie potępiana jako obraz bezwstydu i rozwiązłości. Od 2. poł. XII i w wieku XIII w sztuce europejskiej, głównie włoskiej, powraca antyczne rozumienie piękna cielesnego jako compositum piękna duchowego. Cielesność i duchowość stają się unaoczniane w sztuce w pięknych postaciach męskich i kobiecych, wzorowanych na rzeźbach rzymskich, najczęściej będących kopiami greckich pierwowzorów. Wskazuje się na ożywcze prądy już w rzeźbie francuskiej 2. poł. XII i w XIII wieku, w której w pięknych statui unaocznia się duchowe bogactwo oraz emocjonalną sferę ukazywanych postaci. Ich twarze oraz wysublimowane kompozycje cielesności manifestują etos cnót ${ }^{10}$. Postaci Wenus Genitrix, Wenus Felix, Herkulesa, Fedry,

10 Przykłady zob. R. J u 11 i a n, Les persistances romanes dans la sculpture gothique italienne, „Cahiers de civilisation médiévale X-XII siècles”, 3(1960), s. 295-335. 
Minerwy stały się modelami wzorczymi personifikacji unaocznienia cnót, artes liberales oraz filozofii ${ }^{11}$.

Ambona wykonana przez Nikola Pisana dla baptysterium w Pizie w roku 1260 ukazuje nagą postać Herkulesa jako Fortitudo - cnoty męstwa i siły zarówno fizycznej, jak i duchowej, będące synonimem wszelkich cnót męskich, w tym również honoru ${ }^{12}$. Zwycięski Herkules wykonujący ponadludzkie prace stał się personifikacją również siły duchowej, pokonywania słabości, grzechu zarówno w środowiskach klasztornych, jak i świeckich. W tym obszarze Herkules stanowił uosobienie słabo znanej w badaniach nad ikonografią cnoty Silentio (Milczenie), którą łączono z cnotą wstydliwości (za słowa). W nauce rzymskich cnót łączono milczenie $\mathrm{z}$ mądrością ${ }^{13}$. Interesujące nas wyobrażenie cnoty wstydliwości znalazło w warsztacie Pisanich jedną z najbardziej dosadnych wizualizacji personifikacji cnót w postaci Wenus Pudica, włączonej do programu ambony dla katedry w Pizie (1302-1310). Wykonał ją syn Giovanni, mając już ugruntowany autorytet mistrzowski swoich dzieł, jak fontanna w Perugii, rzeźby w fasadzie katedry sieneńskiej i inne ambony ${ }^{14}$. Wenus Pudica jest tutaj cnotą Prudencji i jako taka wprowadziła jej starożytne znaczenie prudens - doświadczony, obeznany, a w chrześcijańskim rozumieniu cnót - roztropny, rozważny, mądry mądrością nabytego poprzez czyny doświadczenia. W tym właśnie obrębie rozumienia lokalizowano cnotę wstydliwości, doznawaną dzięki umiejętności rozpoznawania wstydu za każdy czyn niegodziwy, nie tylko związany z nagością. Wenus jest Castitas, uosabia nienaganne życie, czystość w działaniu i myśleniu. Posągi Wenus Genitrix i Wenus Felix rozumiano jako Wenus Pudica; łączy je analogiczny sposób

11 N. D a c o s, Arte italiana e arte antica, w: G. P revit a li (ed.), Storia dell'arte italiana, I/3, Torino 1979, s. $12 \mathrm{nn}$.

12 E. P a n of s k y, Die Renaissancen der europäischen Kunst, Frankfurt am Main 1979, s. 76-77, il. 48.

13 R. B. W a d d in g t o n, The Iconography of Silence and Chapman's Hercules, "Journal of the Warburg and Courtauld Institutes", 33(1970), s. 35-60.

14 G. L. Me 11 i n i, Giovanni Pisano, Milano 1971; E. Carli, Il pergamo del Duomo di Pisa, Pisa 1975. 
komponowania. Ukazywane w kontrapoście, czyli nieznacznym odchyleniu od frontalności, delikatnym pochyleniu głowy (ale nie w pełnym skłonie), z prawą nogą wysuniętą do przodu, lewą nieco cofniętą, z jedną ręką diagonalnie uniesioną w górę, podczas gdy druga, opuszczona do bioder, stanowi od czasów greckiej rzeźby topos wizualizacji bogini ideału, miłości, skromności wstydliwości. Ten typ postaci (ubranej lub nagiej) w średniowiecznej i nowożytnej sztuce europejskiej stał się wzorem w ukazywaniu personifikacji cech i cnót kobiecych, zwłaszcza wstydliwości i najbliżej z nią związanych cnót Castitas i Prudencji, czystości, roztropności, prawdy. Taką przedstawia w sztuce nowożytnej np. Sandro Botticelli na obrazie Oszczerstwo wedtug Apellesa, z 1494 roku (Florencja, Galeria Uffizi). Wyobrażenie Prawdy ukazał jako piękną nagą niewiastę (według posągu Wenus medycejskiej, rzymskiej kopii z II wieku przed Chrystusem, posągu greckiego Afrodyty), która jest przeciwstawieniem Kalumni, kobiety ubranej w łachmany ${ }^{15}$.

Personifikacje w sztuce są skumulowanym przekazem obszernej treści - idei, która unaoczniona jest w jednej postaci, szerzej rozumiany sens dopowiadany jest przez widza - odbiorcę znającego ich religijną hermeneutykę. Program cnót i wad spisany został i stopniowo wypracowywany w miniatorstwie wczesnego średniowiecza, znanym w traktacie Aureliusza Prudencjusza, Psychomachii. Stanowił on podstawę dydaktycznych opisów i zaleceń walki duszy ze złem. Przedstawiono ją dosłownie jako walkę postaci kobiecych w sytuacjach bojowych, uzbrojonych w militaria, co wskazuje na tradycję rzymskich Virtus $^{16}$. Jednak w chrześcijańskiej dydaktyce rychło pojawiała się tendencja jednostkowania cnót i wad. Już nie jedna Wirtus, ale liczne figurki lub ich popiersia umieszczano w medalionach tworzących obrazowy katechizm, wyobrażony w kształcie drzew: Arbor Bona - drzewo cnót, lub Arbor Mala. (Jeden z najstarszych tego typu kodeksów Liber Floridus z roku 1120, Gandawa, Bibliothèque de

15 S. M a la g u z z i, Botticelli. Artysta i dzieło, Warszawa 2005.

16 A. K a t z e n e $11 \mathrm{e} \mathrm{n} \mathrm{b} \mathrm{o} \mathrm{g} \mathrm{e} \mathrm{n,} \mathrm{Allegories} \mathrm{of} \mathrm{the} \mathrm{Virtues} \mathrm{and} \mathrm{Vices} \mathrm{in} \mathrm{Mediaeval}$ Art from Christian Times to the Thirteenth Century, New York 1964. 
l’Université de la Ville). W obrębie medalionów, rozumianych jako owoce drzewa dobra, umieszczano cnotę Wstydliwośćc ${ }^{17}$. Uszczegółowienie cnót, w tym cnoty Wstydu i wady Bezwstydu, było rezultatem konkretyzacji grzechów dla celów penitencjarnych. $\mathrm{Z}$ wąskich kręgów elitarnych i zakonnych, korzystających z diagramów zawartych w kodeksach, przeniesiono ten system do szerokiego odbioru, na zewnętrznych fasadach gotyckich katedr. Reliefy umieszczone na poziomie wzroku były niczym rozwinięty zwój, otwarta księga służąca do „czytania” przez szerokie publicum wiernych. Jak potwierdzają badania, najwcześniej tak przygotowany program opracowany został na fasadzie katedry Notre Dame w Paryżu w 1210 roku i powtarzany w analogiczny sposób na fasadach katedr, np. w Amiens (1230), Magdeburgu (1230) i innych fasadach miejskich kościołów, które w ten sposób katechizowały mieszkańców. Tereny wokół katedr, place katedralne i kościelne były miejscami spotkań społeczności miast w dniach świątecznych i codziennych, tam oglądano i kontemplowano również wyobrażenia moralne ${ }^{18}$.

\section{PERSONIFIKACJE CNÓT I WAD}

W dojrzałym średniowieczu cnoty i wady miały swoje konkretyzacje w atrybutach; cnoty ukazywano z kolistymi tarczami wokół głów i w pięknych uwarunkowaniach ciała. Cnota Wstydu ukazywana jest w specyficznym delikatnym skłonie głowy, w pokorze, przesłanianiu twarzy lub ciała, zwrócona trzy czwarte do widza, nigdy frontalnie, czym manifestuje wstydliwość ciała, choć znaczenie wstydu odnosiło się do wszelkiego przewinienia - nie tylko cielesnego. Sztuka katedralna kształtowała moralność, która była tożsama $\mathrm{z}$ etykietą społecznego koegzystowania w środowiskach mieszczańskich. W środowiskach elitarnych opracowywano przekaz cnót i występków, w tym wstydu i bezwstydu, w Księgach Godzin,

17 F. S a x 1, A spiritual Encyclopedia of the later Middle Ages, "Journal of the Warburg and Courtauld Institutes”, 5(1942), s. 85-134, il. s. 27 a-b.

18 A. Kat ze ne 11 e n b o g e n, dz. cyt., s. 75-80. 
np. Livres d'Heures oraz w Zwierciadłach Cnót. Szczególnie bogato przedstawia się w miniatorstwie burgundzko-flamandzkim, włoskim $i$ angielskim w XIV wieku.

W tym miejscu nie sposób pominąć wyjątkowo ważnych dla naszych rozważań polskich zabytków: kolumn zachowanych w zespole klasztornym sióstr norbertanek w Strzelnie. Reliefy personifikacji cnót i wad ukazane są na dwóch kolumnach umieszczonych po stronie północnej i południowej w nawie głównej kościoła pod wezwaniem Świętej Trójcy i Najświętszej Maryi Panny, datowanych na schyłek XII wieku ${ }^{19}$. Pierwowzorem oraz ideowym założeniem rzeźb na kolumnach strzeleńskich, jak się przypuszcza, mógł być traktat Liber Scivias św. Hildegardy z Bingen [?]. Para kolumn w nawie głównej na swoich trzonach w sposób niespotykany pośród zachowanych zabytków ukazuje 36 postaci kobiecych, które gestami rąk, ubiorem, ruchem przekazują sens cnót i wad. Aby umożliwić klarowne czytanie reliefów i kontemplację figur przez zakonnice, trzony podzielone zostały na poziome strefy, a w ich obrębie wydzielono arkady jako miejsca dla kolejnych postaci. Cnoty ukazane zostały na kolumnie południowej - kierunku implikowanym z dobrem; mają koliste nimby. Wady o wyraźnym grymasie twarzy ukazane są na kolumnie północnej; z tym kierunkiem łączono zło. Cnota Wstydu jest tutaj rozumiana łącznie z cnotą Pokory i Czystości, ukazana z kwiatem lilii. Zgodnie z katalogiem cnót nauczanych w zakonach żeńskich, u podłoża tych dwu cnót była cnota Wstydliwości, należąca do istotnych uwarunkowań kobiecych.

Na kolumnie północnej ukazane zostały wady: Gniew, Pycha, Obżarstwo, Morderstwo, Krzywoprzysięstwo, Zawiść. Interesujące dla naszych rozważań są dwie stojące obok siebie postaci: naga kobieta przysłaniająca ciało w sposób identyczny do znanych już postaci Wenus, obok stoi niewiasta, która zdaje się rozwiązywać szatę.

19 Z. Ś w i e c how s k i, Strzelno romańskie. Początki Strzelna na tle regionu i jego sieci drożnej, w: Strzelno Romańskie. Zbiór studiów, Strzelno 1972, s. 5-24; M. W a 1 i c k i, Sztuka polska przedromańska i romańska do schyłku XIII wieku, t. 1, Warszawa 1968, s. 213. 
Naga postać zinterpretowana została jako Wenus, którą w epoce romańskiej utożsamiano z Nieczystością ${ }^{20}$. Podejmując jednak kontekst funkcji rzeźb, czas ich powstania i miejsce, należałoby przyjąć interpretację biblijną. Dwie personifikacje, ukazane obok siebie na północnej kolumnie suponującej zło, to Ewa, przedstawiona jako naga postać, protoplasta grzechu i doznawanego wstydu, a obok niej kobieta ubrana, zdająca się rozbierać, która jest rozumieniem memento przed Bezwstydem, niespełnionym grzechem, stanowiącym w katalogu cnót kobiecych powód wszelkiego grzechu, identyczny $\mathrm{z}$ brakiem lęku wobec Boga.

O ile personifikacje były jednopostaciowym unaocznieniem obszernej kwestii, którą należało rozpoznać w szerszym kontekście wiedzy, o tyle ilustracje zdarzeń, przekazanych głównie na podstawie Biblii, dotyczące interesującego nas zagadnienia wstydu, unaoczniają narrację międzyosobową, oddają wygląd cielesny i cechy emocjonalne postaci biorących udział w ukazanym wydarzeniu. Nie bez znaczenia jest kontekst miejsca oraz temporalności wyobrażenia, a nade wszystko emocjonalna skala ukazanych postaci. Wizualizacja wstydu ugruntowana w sztuce odnosiła się do scen, których przesłaniem nie było jedynie doświadczenie uczucia wstydu wynikającego z nagości. Problem ten wymagałby szerszej analizy, w tym miejscu odwołamy się do najważniejszych zagadnień unaoczniania wstydu i wstydliwości w obrębie zdarzeń biblijnych. Przykładem jest rozpowszechniana w malarstwie flamandzkim XV wieku scena Betsabe w kąpieli. W bogatym społeczeństwie Księstwa Niderlandzkiego w XV wieku sceny kąpieli Betsabe lub Zuzanny były szczególnym przesłaniem dla ówczesnych odbiorców. Ogromnym uproszczeniem byłoby odnosić je tylko do prezentacji ciała kobiecego i łączyć z bezwstydem, grzechem, brakiem cnoty czystości. Ukazywana wstydliwość Betsabe miała być memento dla kobiet, szczególnie mężatek. Wychodzącą z kąpieli Betsabe malowali najwybitniejsi malarze tamtego czasu, np. Jan van Eyck (obraz zaginiony) czy Hans Memling (Stuttgart, Staatsgalerie). Ich dzieła są kunsztem artystycznej doskonałości

20 Z. Ś w i e c how s k i, dz. cyt., s. 17. 
ukazującej nagie ciało kobiece, a sam motyw w środowisku bogatego mieszczaństwa Flandrii był unaocznieniem czystości.

Liczne są wyobrażenia w sztuce, już we wczesnych miniaturach kodeksów wczesnego średniowiecza, ukazujące pijanego Noego. Doświadczenie wstydu przekazują synowie Noego, przysłaniający nagość ojca; odwróceni tyłem okrywają go płaszczem ${ }^{21}$.

Cnotą wstydu i zarazem pokory jest nagość Hioba. Hiob może być wzorem wszystkich cnót wobec Boga; unaocznia cierpienie spowodowane między innymi obnażeniem, nagością i rozkładem ciała, stając się prototypem Chrystusa cierpiącego i obnażonego. Zatem nagość nie może być w poszukiwaniach sensu wstydu kryterium wyjaśnienia formy. Nie była bowiem jednoznacznym synonimem bezwstydu, acz w sztuce problem ten znalazł unaocznienie w wielu motywach ukazujących konkretne zdarzenia.

Dawid, ukazany w miniaturach karolińskich, tańczy nago przed Bogiem; nie jest to wynik braku wstydu, lecz pełnej radości oddania się Bogu w tańcu i śpiewie przy dźwiękach harfy. Znajdujemy w tym nawiązanie do wyobrażeń antycznego Orfeusza, który był również figurą Chrystusa Dobrego Pasterza ${ }^{22}$. Nagość związana z pełną ofiarą dla Boga ukazana była w scenie ofiary Izaaka, złożonej przez jego ojca Abrahama. Biblia nie wspomina ubioru, natomiast już średniowieczna sztuka ukazywała nagiego chłopca złożonego na drwach, np. na reliefie kapitelu katedry w Jaca (Hiszpania). W scenie ofiary Abrahama syn jest nagi. Ten sposób ukazywania Izaaka będzie stałym modelem w sztuce nowożytnej, a nagie ciało ofiarowanego syna rozumiane jest jako czysta ofiara złożona Bogu ( $\mathrm{Rdz} 22)$.

Ponieważ zagadnienie wstydu - bezwstydu w scenach biblijnych, ukazanych w sztuce chrześcijańskiej, nie ma pełnego opracowania, wymagałoby obszernego studium, możemy jedynie w tym miejscu zasugerować problem godny szerszego badania w aspektach antropologii biblijnej i historycznej.

${ }^{21}$ Problem omawia szeroko M. H. C a v i n e s s, A Son's Gaze of Viriliphobia?, w: The Meanings, s. 103-148.

22 I. J. J e s n i c k, The Image of Orpheus in Roman Mosaic, Bar 1997. 


\section{WSTYD ADAMA I EWY}

Niewątpliwie najgłębiej $\mathrm{w}$ teologii podejmowana jest kwestia wstydu pierwszych Rodziców po grzechu pierworodnym. Zakres materiału ilustracyjnego stanowiłby odrębne studium, acz ten problem został już dostrzeżony w analizach sztuki. Doświadczenie wstydu człowieka po raz pierwszy w tekstach biblijnych zostało jednoznacznie przedstawione w drugim opisie Księgi Rodzaju. Warto zaznaczyć, że autor opisujący stworzenie człowieka i jego pobyt w raju nie wyjaśnia stanu emocjonalnego i przeżyć Adama i Ewy. Niewątpliwie jest to stan szczęśliwości, która nie znalazła swoich analogii w życiu człowieka na ziemi, stąd zamknięta została do stanu idealnego, który powróci w zmartwychwstaniu i ponownym wejściu człowieka do nieba. Komentarze ojców Kościoła i teologów średniowiecznych więcej miejsca poświęcają duchowej i uczuciowej kondycji pierwszych Rodziców, analizując konteksty wszystkich dni stworzenia, nie tylko dnia szóstego ${ }^{23}$. Komentarze do Księgi Rodzaju, a w związku z nimi powstające ilustracje, zdecydowanie większą uwagę przywiązywały do interpretacji stworzenia światła i ciał niebieskich, następnie przyrody, roślin, zwierząt. Stworzenie człowieka skupiło się w ilustracjach na sposobach ukształtowania ciał Adama i Ewy oraz ich obecności w raju, następnie na grzechu pierworodnym i wyjściu z raju. Artyści podejmowali wysiłki, aby oddać cielesność stworzonych Rodziców oraz otoczenie rajskie z drzewami i roślinnością. Uderzający jest idealny stan bezemocjonalnej egzystencji Adama i Ewy przed grzechem. Jedynym wydzielonym i nazwanym uczuciem jest wstyd; najpierw go nie odczuwali, będąc w raju, , chociaż mężczyzna i jego żona byli nadzy, nie odczuwali nawzajem wstydu" (Rdz 2, 25). Po

23 Św. A m broż y, Hexaemeron, (tłum. W. Szołdrski CSsR), Warszawa 1969, passim; Grzegor z z Nys s y, O stworzeniu człowieka, wstęp, (tłum. M. Przyszychowska), Kraków 2006; M. S z r a m, Ciało zmartwychwstałe w myśli patrystycznej przełomu II i III wieku, Lublin 2010. Szersza literatura na temat stwarzania pierwszych Rodziców przez Stwórcę i ich wyglądu cielesnego zob. U. M a z u r c z a k, Cielesność człowieka $w$ średniowiecznym malarstwie Italii, t. I, Lublin 2012, s. 35-124. 
zerwaniu owocu z zakazanego drzewa pierwszym doświadczeniem jest wstyd wzajemny wobec swoich nagich ciał: „A wtedy otworzyły się im obojgu oczy i poznali, że są nadzy; spletli więc gałązki figowe i zrobili sobie przepaski” (Rdz 3, 7). Uczucie lęku i wstydu pojawiło się po raz drugi, gdy słyszeli głos zbliżającego się Boga, ,(...) przestraszyłem się, bo jestem nagi, i ukryłem się (...)" (Rdz 3, 10) $)^{24}$. Grecki tekst podkreśla fakt doświadczenia wstydu nagością i tym samym okrycia ciała ubiorem, „Pan Bóg, sporządził Adamowi i jego żonie chitony ze skór i tak ich przyodział" (LXX, Rdz 3, 21$)^{25}$.

Skala tego uczucia została w sztuce ukazana w sposób niezwykle zróżnicowany. Jako najstarsze spośród zachowanych modeli iluminacji do Księgi Rodzaju uznaje się miniatury w kodeksie purpureus pochodzenia wschodniego, przechowywanym w Bibliotece Narodowej w Wiedniu, Wiener Genesis z końca VI wieku ${ }^{26}$. Rodzice ukazani w scenie po zerwaniu owocu są zgięci, pochyleni ku ziemi; wstyd i lęk zmieniły ich wyprostowaną postawę, którą różnili się od zwierząt, jak podkreślił w swoim komentarzu św. Ambroży. Pochyleni i zdeformowani, gestami rąk zakrywają ciało. Opuszczają raj w swoich okryciach ze skór zwierzęcych. Ukazane tutaj postaci oddają uczucie wstydu jako stan emocjonalny, dojmujący, który przemienił cały ich wygląd. Miniaturzyści karolińskich obrazów zamieszczonych w Bibliach, powstałych np. w Saint-Denis, w Tours, w IX wieku, skupili uwagę na oddaniu wstydu poprzez zakrycie części wstydliwych ciała, jednak postawa Rodziców pozostała wyprostowana. Uczucie wstydu pierwszych Rodziców dosadnie ukazane zostało na rzymskim

24 Wszystkie cytaty za: Pismo Święte Starego i Nowego Testamentu w przekładzie z języków oryginalnych, opracował zespół biblistów polskich z inicjatywy benedyktynów tynieckich, Poznań-Warszawa 1971.

25 Septuaginta czyli Biblia Starego Testamentu wraz z ksiegami deuterokanonicznymi i apokryfami, przełożył, przypisami i wstępem opatrzył R. Popowski SDB, Warszawa 2014, s. 9.

26 B. Z i m m e r m a n nie Wiener Genesis im Rahmen der antiken Buchmalerei. Ikonographie, Darstellung, Illustrationsferfahren und Aussageintention, Wiesbaden 2013. 
sarkofagu Juniusa Bassusa z połowy IV wieku ${ }^{27}$. Ten właśnie rzymski sposób ukazywania wstydu w fizjonomiach przetrwał w środowisku średniowiecznych miniaturzystów.

Na podstawie analizy grupy obrazów pierwszych Rodziców po grzechu pierworodnym, ukazanych w malarstwie Italii w okresie średniowiecznym (nowożytność na tych się wzorowała) można pokusić się o pewną fenomenologię wstydu Adama i Ewy. Odwróceni zazwyczaj bokiem do siebie: wstydzą się siebie samych i wobec siebie, stąd przysłonięcie jedną ręką twarzy, drugą zaś dolnej części ciała. Ugięte nogi w kolanach wskazują na uczucie lęku, towarzyszące wstydowi. Poszukując pierwowzoru postaci dla ukazania wstydu, napotykamy na antyczne modele bogini Afrodyty-Wenus, której pierwowzór gestów kontrapostu oddawał cnotę wstydliwości. Ten pierwowzór podjęty został i zaadaptowany do podkreślenia wstydu pierwszych Rodziców w raju po grzechu pierworodnym. Jako taki nie dotyczył ciała, ale przekroczenia zakazu - woli Boga. Zatem wstyd ukazywany poprzez gesty i sposób kreowania cielesnego został odniesiony do grzechu w ogóle i wstydu wobec prawa Boga.

Wyobrażenia powstałe w malarstwie i plastyce Italii w XIII i XIV wieku, np. mozaiki w kopule narteksu katedry San Marco w Wenecji z poł. XIII wieku, mozaiki w baptysterium we Florencji, w katedrze w Monreale, freski w baptysterium w Padwie, zbliżone w swoim artystycznym przekazie ukazują Adama i Ewę w kontrapoście ze zgiętymi kolanami i zdeformowanymi lękiem i przerażeniem twarzami ${ }^{28}$.

Studia wizualizacji narracji Księgi Rodzaju koncentrowały się na różnych zagadnieniach, szczególnie wyobrażeniach samego Stwórcy, pomijały zaś genezę i sposób komponowania Rodziców po dokonaniu grzechu pierworodnego. Wstyd koncentruje się i odbija w twarzy, stąd chęć jej zakrycia, przysłonięcia delikatnie uniesioną dłonią. Duże

27 Obecnie skarbiec Bazyliki św. Piotra, Watykan - za: E. J a s t r z ę b o w s k a, Sztuka wczesnochrześcijańska, Kraków 2008, s. 89.

28 U. M a z u r c z a k, dz. cyt., s. 70-124; M. B u c h s e 1, H. L. K e s s le r, R. M ü 11 e r, The Atrium of San Marco in Venice. The Genesis and Medieval Reality of the Genesis Mosaics, Berlin 2014, passim. 
znaczenie mają gesty, i odmiennie aniżeli w momencie stworzenia, ukształtowane ciała, które stały się teraz korpulentne, a ugięte kolana oddają lęk i niepewność w poruszaniu się.

W cyklicznych wizualizacjach Księgi Rodzaju w XIII i XIV wieku ukazywano często w Italii sceny następujące po grzechu pierworodnym, których nie zapisali autorzy biblijni, a które są wynikiem późniejszych komentarzy i pobożności późnośredniowiecznej, odnoszącej się do Miłosierdzia Boga. Były one niejako zaprzeczeniem apokryficznych przekazów krążących w średniowieczu i nowożytności o „złym nasieniu” Ewy ${ }^{29}$. Można wskazać rozszerzone programy ikonograficzne narracji Genesis, na wprowadzone sceny ukazujące pierwszych Rodziców, którzy po grzechu pierworodnym, zanim opuszczą raj, klęczą u stóp Boga. Ubrani są w tuniki, które nie są już krótkimi chitonami ze skóry, lecz długimi szatami symbolizującymi ubranie Nowego człowieka, dane przez chrzest i sakrament pokuty. W cyklu ilustracji do Księgi Rodzaju sceny te wprowadzają nową interpretację wstydu za grzech pierworodny; zyskuje on wsparcie łaską Boga. Zagadnienie to jest w trakcie badań autorki, wskazała na ten problem w analizie fresków w kaplicy św. Katarzyny w Solaro ${ }^{30}$.

Ukazywanie uczucia wstydu Adama i Ewy po grzechu pierworodnym podejmowała sztuka jako zdarzenie odrębne pod względem scenicznym. Wstydliwe zakrywanie ciała wprowadzali artyści już w momencie dotyku owocu, zanim zostanie zerwany, albo w chwili jego zrywania. W ten sposób akcentowano istnienie grzechu już w jego zamyśle, zanim zostanie on dokonany.

Na przyporządkowanie wstydu czynowi lub uczuciu wskazywał św. Tomasz z Akwinu, analizując sferę uczuć człowieka. Stwierdził, że Adam nie posiadał cnoty wytrwałości, ponieważ popełnił grzech „,nie miał więc wszystkich cnót"31. Brak wszystkich cnót Adama przenosi się również na Ewę. Ukazywani są w raju w momencie stworzenia,

\footnotetext{
29 M. S t a r o w i e y s k i (red.), Apokryfy ewangeliczne, t. I, Lublin 1980, s. 81.

30 U. M a z u r c z a k, dz. cyt., s. 104-110.

31 Św. Tom a s z z A kw in u, Suma teologiczna, t. VII: O człowieku (I, q. 85-102), (tłum. P. Bełch), London 1980, art. 3, 4, s. 95.
} 
stoją wyprostowani obok drzewa poznania, zaś po skosztowaniu owocu ich postaci przedstawione są $\mathrm{w}$ identycznym zachowaniu: przesłanianiu ciała, zdeformowanych obliczach, ich ruchy, gesty są identyczne, odwróceni są w przeciwnym kierunku wobec Stwórcy, pochyleni, przepełnieni wstydem ${ }^{32}$. Św. Tomasz rozwija tę kwestię, wspomagając się autorytetem św. Augustyna. Objaśnia: „Po przekroczeniu Bożego zakazu natychmiast opuściła ich łaska Boska i zaczęli wstydzić się swoich ciał. Przysłanianie twarzy jest czymś nowym w ich zachowaniu. Po stworzeniu stali przed obliczem Boga, na Którego mogli patrzeć twarzą w twarz, co w sposób niezwykle dobitny w scenach stworzenia Adama i następnie Ewy ukazywali artyści italscy od XII wieku ${ }^{33}$.

Kończąc nasze rozważania związane z zagadnieniem wizualizacji w sztuce uczuć wstydu, nie podjętych do tej żadnymi badaniami, warto wskazać na sceny Zwiastowania Maryi i kompozycje Dziewicy, które w kontekście scen grzechu pierworodnego Rodziców mają szczególne powinowactwo zarówno dogmatyczne, jak i sposób ich artystycznego przekazu ${ }^{34}$.

\section{CNOTA WSTYDLIWOŚCI NAJŚ WIĘTSZEJ MARYI PANNY}

Znany jest związek Zwiastowania ze scenami w raju, w badaniach wyobrażeń w sztuce, co ma swoje korzenie w tekstach i komentarzach teologicznych. Jednym z najbardziej rozwiniętych spośród zachowanych tego typu cykli są freski w kościele San Giovanni pod Porta Latina w Rzymie z 2. poł. XII wieku ${ }^{35}$. Sposób przedstawienia Maryi w scenie Zwiastowania nasuwa świadome nawiązanie do Ewy w scenie grzechu

32 Tamże.

33 U. M a z u r c z a k, dz. cyt., rozdz. I.

34 A. P a c i o r e k, U. M a z u r c z a k, Gdy Jezus narodzit się w Betlejem. Ewangelia dzieciństwa z komentarzem teologiczno-biblijnym i ikonograficznym, Lublin 2005.

35 S. R o m a n o, Riforma e Tradizione 1050-1198. La pittura medievale a Roma 312-1431. Corpus e Atlante, vol. IV, Roma 2016, s. 348-371; U. M a z u r c z a k, dz. cyt., s. $229 \mathrm{nn}$. 
pierworodnego. Artysta podkreślił gestem ręki oraz ruchem całego ciała analogie między Ewą a Maryją jako Nową Ewą w momencie Zwiastowania - poczęcia Jezusa. Wizualizacja jest czytelna, jednocześnie podkreśla odrębność postaci Maryi, tak jak odrębne jest doświadczenie wstydu Ewy według opisu Księgi Rodzaju z wstydliwością Maryi. Maryja bez grzechu poczęta - Niepokalana nie unaocznia wstydu, ale cnotę wstydliwości razem z pełnią wszystkich cnót. Doświadczenie wstydu Ewy jest najgłębszą cnotą wstydliwości Nowej Ewy - Maryi. Uwidocznienie tej wydawałoby się paraleli, wstyd-wstydliwość, nie jest bezpośrednim przeniesieniem powinowactwa w formie przekazu, ale unaocznieniem pełni cnót, w tym cnoty wstydliwości.

Od końca XII i w wieku XIII dominującym centrum artystycznym był Rzym. Tutaj tworzyli znakomici artyści, wprowadzający pogłębioną o nowe znaczenia treściowe wizualizację scenicznego przekazu, szczególnie w obrębie scen Maryjnych, czego przykładem jest fresk Piotra Cavalliniego (XIII/XIV w.) w kościele św. Cecylii w Rzymie, datowany na około 1290 rok $^{36}$. Analogiczna jest kompozycja Maryi w scenie Zwiastowania na mozaice w kościele Santa Maria in Trastevere w Rzymie ${ }^{37}$. W tym miejscu możemy wskazać na kontynuację tradycji unaocznienia Maryi pokornej - wstydliwej w scenach Zwiastowania powstałych w środowiskach artystycznych: Neapolu, Sieny, Florencji i Mediolanu, w XIV i XV wieku. W analizach malarstwa Duccia di Buoninsegna (1255-1318), Simone Martiniego (1284-1344), braci Lorenzettich: Ambrogia (1290-1340) i Piotra (1280-1348) podkreśla się wyjątkowo klarowne artystyczne wypracowanie cnót maryjnych. Istnieją rozpoczęte w tym kierunku obszerne badania H. W. van Osa, które na podstawie zebranego katalogu sieneńskich obrazów maryjnych wykazały szczególny pietyzm artystów w unaocznianiu pokory Maryi. Autor w obrębie omawianych dzieł nie wydziela szczególnej cnoty wstydliwości ${ }^{38}$. Można podjąć takie

\footnotetext{
36 P. To e s c a, Pietro Cavallini, Milano 1960, s. 6 nn.

37 U. M a z u r c z a k, dz. cyt., s. 229-280.

${ }^{38}$ H. W. va n O s, Marias Demut und Verherrlichung in der sienesischen Malerei 1300-1450, Gravenhage 1969.
} 
rozważania na podstawie porównań kompozycji formalnych i tekstowych źródeł, zaproponowanych w niniejszym artykule, z innymi centrami artystycznymi w Italii (Florencji, Lombardii), w Czechach i w Polsce. Pełna jednak analiza formalna oraz ikonograficzna cnoty wstydliwości wymaga wskazania źródeł tekstowych, co w tym miejscu może jedynie zasugerować autorka badająca ten specyficzny przekaz cnoty Maryi, wskazując na św. Bernarda z Clairvaux, jego komentarze i kazania, zwłaszcza na uroczystość Zwiastowania Najświętszej Maryi Panny. Problem ten wymaga pogłębionych studiów ikonografii Maryi, np. scen Wniebowzięcia i Maryi Niepokalanie Poczętej, szczególnie intensywnie unaocznianej w sztuce nowożytnej.

\section{From the realm of presenting the theme of 'shame' in art, on selected examples in European and Polish medieval art Summary}

Shame is a feeling, it is definable in the areas of psychology, history of culture, and customs in the analyses of the history of religion and ethics. Shame defines the relationship between the object of shame and the subject of this feeling and, ultimately, the subject may not feel ashamed because of an act or a fact, which is not, for him or a certain moral and religious community, understood as a reason for shame. A slightly different, but also related to the concept of 'shame ', is the notion of 'bashfulness' understood as a human capability to feel shame to the same extent as the pursuit of other virtues: love, being sensible, faith, chastity, hope, but also humility, modesty and silence. 'Bashfulness ' is an integral part of the condition of a decent, fair and noble life, which in the Roman social education was defined by one common virtue - 'virtus ', known in Greece as 'arete'. The Christian understanding of virtues and vices, described by Prudentius and later on studied in detail in various texts and works of art by E. Saxl, and A. Katzenellenbogen, specified in detail both virtues and vices at the same time following ancient models.

The author undertakes the analysis of the phenomenon of 'shame' in the visualisation of Christian, especially medieval, art starting from the accounts of important biblical citations on the 'shame' theme. Then she attempts to point out stage images illustrating the religious or moral problem of shame commonly referred to nudity, which, however, is not a proper understanding of shame and bashfulness. The study 
focuses on selected issues: personification of shame and on the events (described in the Old Testament) which imply shame. The selected images are illustrations of Genesis cycle where the First Parents' feeling of embarrassment was depicted. The author indicates the sources of ancient compositions of the Aphrodite statue-Venus Pudica, which developed the topos of 'shame' and 'bashfulness' imagery. This type of nudity constitutes a distinctive programme of gestures, movement, counterpose and the composition of the head. They are a clear visualisation of the female ideal - of virtues, including the virtue of an ideal love that was associated with bashfulness. The validity of this theme in Italian medieval art, especially in Nicola and Giovanni Pisanos' works, was pointed out. The personifications of virtues: Venus Pudica or Hercules shown on reliefs in pulpits in Pisa, confirm the validity of the theme of 'bashfulness' in medieval art.

In the cathedral sculpture, on the outer facades, the sets of virtues and vices used to be depicted, and they were supposed to be addressed to the wide audience of urban publikum. The author of the study pointed out the reliefs of cathedral facades in Paris, Amiens, Magdeburg in which the virtues, including the virtue of shame, had been presented. The columns in the Church of the Norbertine monastery in Strzelno are of great significance for European art. The author also suggested a new iconographic interpretation for the naked figure of Venus pucica.

The second field of research is the issue of narrative scenes, the visualisations of nudity based on the Bible, that constitute a positive sense of understanding naked figures in Christian art: Bathsheba in bath, the dancing King David, the suffering Job and the naked, drunken Noah. The author focuses on the analysis of the complex and non-uniformly presented Adam and Eve's narrative of the feeling of shame. The moments when they experience the feeling of shame and their nudity for the first time are diversified. The author of the Book of Genesis does not mention first parents' other feelings in paradise, the only statement is the lack of being ashamed of their body at the moment of creation and then the experience of shame after the original sin. The author included more extensive research on the visualisation of the Genesis narrative in her book Human Corporeality in the medieval Italian painting, Vol.I, Lublin 2012. The experience of the first parents' embarrassment when recognising their nudity was, at the same time, the experience of a permanent virtue of bashfulness. In the Italian series of Genesis imaging the parents experience grace due to the shame they suffered. Additional scenes, which were introduced into cyclical narratives of Genesis and which confirm the meaning of Divine Mercy in the cycle ending the creation of man, are pointed out in the study.

Słowa klucze: wstyd, nieśmiałość, cnota, nagość, łaska

Key words: shame, bashfulness, virtue, nudity, grace 
Nota o autorce: prof. dr hab. Urszula Mazurczak - historyk sztuki na Wydziale Nauk Humanistycznych KUL; w latach 1993-2014 kierownik Katedry Historii Sztuki Średniowiecznej, w latach 1995-1999 dyrektor Instytutu Historii Sztuki.

\section{Bibliografia}

Ambroży św., Hexaemeron, tłum. W. Szołdrski CSsR, Warszawa 1969.

Apokryfy ewangeliczne, t. I, red. ks. M. Starowieyski, Lublin 1980.

Arystoteles, Etica nicomachea IV,7,1124a-8.1125.

Buchsel M., Kessler H.L., Müller R., The Atrium of San Marco in Venice. The Genesis and Medieval Reality of the Genesis Mosaics, Berlin 2014.

Carli E., Il pergamo del Duomo di Pisa, Pisa 1975.

Caviness M.H., A Son's Gaze of Viriliphobia?, [w:] The Meaning of Nudity in Medieval Art, ed. S.C.M. Lindquist, Burlington (USA) 2012, s. 103-148.

Dacos N., Arte italiana e arte antica, [w:] Storia dell'arte italiana, I/3, ed. G. Previtali, Torino 1979.

Enciclopedia dell'Arte Antica Classica e Orientale, t. VIII, Roma 1966.

Grzegorz z Nyssy, O stworzeniu człowieka, wstęp, tłumaczenie, przypisy M. Przyszychowska, Kraków 2006.

Histoire du corps, t. I-III, red. A. Corbin, J. Vigarello, Paris 2005 (tłum. polskie T. Stażyński, Historia ciała, t. I-III, Gdańsk 2011).

Historia życia prywatnego t. I-II, red. P. Veyne, tłum. W. Gilewski, K. Skawin, Wrocław 1998.

Jastrzębowska E., Sztuka wczesnochrześcijańska, Kraków 2008.

Jesnick I.J., The Image of Orpheus in Roman Mosaic, Bar 1997.

Jullian R., Les persistances romanes dans la sculpture gothique italienne, „Cahiers de civilisation médiévale X-XII siècles" 3 (1960), s. 295-335.

Katzenellenbogen A., Allegories of the Virtues and Vices in Mediaeval Art from Christian Times to the Thirteenth Century, New York 1964.

Le Goff J., Troung N., Historia ciała w średniowieczu, tłum. I. Kania, Warszawa 2006.

Long J.C., The Survival and Reception of the Classical Nude: Venus in the Middle Ages, [w:] The Meaning of Nudity in Medieval Art, ed. S.C.M. Lindquist, Burlington (USA) 2012.

Malaguzzi S., Botticelli Artysta i dzieło, Warszawa 2005.

Mazurczak U., Cielesność człowieka $w$ średniowiecznym malarstwie Italii, t. I, Lublin 2012, s. 35-124. 
Mellini G.L., Giovanni Pisano, Milano 1971.

Os H.W. van, Marias Demut und Verherrlichung in der sienesischen Malerei 1300-1450, s-Gravenhage 1969.

Paciorek A. ks., Mazurczak U., Gdy Jezus narodzit się w Betlejem. Ewangelia dzieciństwa z komentarzem teologiczno-biblijnym i ikonograficznym, Lublin 2005.

Panofsky E., Die Renaissancen der europäischen Kunst, Frankfurt am Main 1979.

Pismo Święte Starego i Nowego Testamentu w przekładzie z języków oryginalnych, oprac. zespół biblistów polskich z inicjatywy benedyktynów tynieckich, Poznań-Warszawa 1971.

Romano S., Riforma e Tradizione 1050-1198. La pittura medievale a Roma 312-1431. Corpus e Atlante, vol. IV, Roma 2016.

Saxl F., A spiritual Encyclopedia of the later Middle Ages, "Journal of the Warburg and Courtauld Institutes" 5 (1942), s. 85-134.

Septuaginta czyli Biblia Starego Testamentu wraz z księgami deuterokanonicznymi i apokryfami, przełożył, przypisami i wstępem opatrzył R. Popowski SDB, Warszawa 2014.

Słownik języka polskiego, red. W. Doroszewski, t. IX, Warszawa 1967.

Szram M. ks., Ciało zmartwychwstałe w myśli patrystycznej przełomu II i III wieku, Lublin 2010.

Szram M. ks., Cnota pokory w nauczaniu greckich Ojców Kościoła IV wieku, Lublin 2014.

Świechowski Z., Strzelno romańskie. Początki Strzelna na tle regionu i jego sieci drożnej, [w:] Strzelno Romańskie. Zbiór studiów, Strzelno 1972, s. 5-24.

Toesca P., Pietro Cavallini, Milano 1960.

Tomasz z Akwinu św., Suma teologiczna, t. VII: O człowieku (I, q. 85-102), tłum. P. Bełch, London 1980.

Tomasz z Akwinu św., Suma teologiczna, t. X: Uczucia (I-II, q. 22-48), przeł. J. Bardan, obj. prof. F.W. Bednarski OP, London 1965.

Waddington R.B., The Iconography of Silence and Chapman's Hercules, "Journal of the Warburg and Courtauld Institutes“ 33 (1970), s. 35-60.

Walicki M., Sztuka polska przedromańska i romańska do schyłku XIII wieku, t. I, Warszawa 1968.

Zimmermann B., Die Wiener Genesis im Rahmen der antiken Buchmalerei. Ikonographie, Darstellung, Illustrationsferfahren und Aussageintention, Wiesbaden 2013. 